\title{
African Identity, Self and Other, in Obama's Dreams from My Father
}

\author{
Azza Ahmed Heikal \\ College of Language and Communication, Arab Academy for Science and Technology \& Maritime Transport, Cairo, Egypt \\ Heba Mohamed Abdel Aziz (Corresponding author) \\ College of Language and Communication, Arab Academy for Science and Technology \& Maritime Transport, Cairo, Egypt \\ E-mail: heba_bibo2001@hotmail.com
}

Doi:10.7575/aiac.alls.v.7n.1p.248

URL: http://dx.doi.org/10.7575/aiac.alls.v.7n.1p.248
Received: 09/10/2015

Accepted: 23/12/2015

\begin{abstract}
This paper is a close examination of postcolonial and postmodern 20th century discourse with reference to Obama's Dreams from My Father_(1995). Barack Hussein Obama (1961-present) has a colonial experience and double cultural background which formulate his views of racial discrimination, make him accept racial differences and dream of uniting the divided colors one day. The study focuses on his autobiographical narrative within the framework of postcolonialism and postmodernism.
\end{abstract}

Keywords: post modernism, post colonialism, identity construction

\section{Introduction}

Although the apartheid era in Africa has reached an end, it left some inherited notions of apartheid and race that exposed Africa to socio-economic division; accordingly, a group of activists appeared calling for a sort of recognition of the indigenous societies and their rights. Among the figures calling for the recognition of marginalized societies is the Afro-American president Barack Hussien Obama.

Actually, Obama is one of those who are influenced by the events taking place all over the world like the fall of Berlin Wall in 1989, the beginning of the era of globalization and the fall of the two towers in 9/11. These events are supposed to be turning points to the whole world in all its fields i.e. the economic, social, cultural, political fields as well as the literary field. Such events have insinuated some conflicts inside the whole society in general and inside the individual in particular. These conflicts raised issues related to identity, race, gender, power and religion; so, writers of the $20^{\text {th }}$ century express their experiences and attitudes through their writings and the new narrative techniques they use.

This paper examines the post-colonial and postmodern aspects of the autobiographical narrative text Dreams From My Father. This study is a cross-cultural one; it makes use of post- colonialism and postmodernism as analytical tools with special reference to the postcolonial theorists Frantz Fanon, Edward Said and Ihab Hassan. Tracing the theme of culture clash and the technique used to convey such theme reveal whether the selected writer is writing from a state of stability and confidence or from that of insecurity and infidelity and whether the two cultures he experienced are mirroring or rejecting each other.

\section{Research Objectives}

The study aims at presenting a thorough study of Obama's Dreams From My Father (1995). Obama is especially chosen for this study for one main reason; although Obama is an American President, his writing style is very artistic. Obama is considered to be a dreamer and a reformer. The study argues that the analysis of Obama's writings can, hopefully add to a deep understanding of how different cultural backgrounds are reflected on the person's concepts. That is, Obama feels that although he belongs to the minority, he is still superior due to education, freedom and upbringing.

Dreams From My Father is discussed in terms of post-colonialism and postmodernism and their relation to cultural identity. Also a reference to cultural and narrative theories is included. The aim of the study is to discuss the narrative as the umbrella under which political texts, short stories, novels and autobiographies could be studied. Thus, a literary review on culture and narrative theories will be introduced. Postmodernism and post colonialism will be tackled since their impact on narrative and culture is inseparable.

This study probes into postmodernism and post-colonialism as two interrelated literary approaches. In other words, studies in post-colonialism and postmodernism will be utilized to unravel the political and the psychological meanings of the current events taking place in the modern world and how the idea of the 'One' and the 'Other' and the exploration of the 'self' are presented in the selected narratives of Obama. 


\section{Research Questions}

The study seeks to answer the following questions within the frameworks of post modernism and post colonialism:

1. How a person's concepts vary cross culturally?

2. Do culture, place, time and origin affect theme and technique?

3. How Obama's autobiography is placed between present and past as well as self and other?

\section{Review of Literature}

Post colonialism is a term used to refer to the struggle against colonial domination and its legacies of control. It includes races that have been culturally and intellectually colonized by western ideas and beliefs. According to Ania Loomba in Colonialism/Post colonialism (1998), 'It has been suggested that it is more helpful to think of Post colonialism not just as coming literally after colonialism and signifying its demise, but more flexibly as the contestation of colonial domination and the legacies of colonialism' (12). So, post colonialism is indebted to colonialism as the former was born in the latter's atmosphere as a response to the aggression and fake ideology of colonialism. Moreover, in The Empire Writes Back (1989), Ashcroft, Griffiths and Tiffin employ the concept 'to cover all the cultures affected by the imperial process from the moment of colonization to the present day.' (2).

To understand the relationship between the colonizer and the colonized and how the former affects the latter, it is important to focus on the colonized and delve deep into his psyche. Among the most prominent critics in the field of post-colonialism is the psychologist Frantz Fanon. Fanon's Black Skin White Masks (1952) and The Wretched of the Earth (1968) are considered unsurpassed studies of the black psyche in a white world as they present a deep analysis of the psychological as well as the sociological impact of colonization. They are concerned with the psychologies of the oppressed people and their image of themselves. In Black Skin White Masks, Fanon writes about his experience of racism as a black man. According to Fanon: 'I took myself far off from my own presence, far indeed and made myself an object... All I wanted was to be a man among other men. I wanted to come lithe and young into a world that was ours and to help to build it together' (112-113). Fanon rejects the inferiority complex and tries to encourage the blacks to act positively to seek social justice and to resolve their conflicts.

In The Wretched of the Earth, Fanon portrays the relationship between the colonizer and the colonized and how it is primarily based on violence. The colonizer falsely claims that he is the only means to salvation from wilderness and barbarism. According to Fanon, '[The colonizer] dehumanizes the native... [and] turns him into an animal' (42). It is no doubt that the racial prejudice encouraged the whites to humiliate the Negroes and to deprive them of any human rights. Actually, these two books serve in arousing people's awareness and accordingly many racially oppressed people started to struggle in order to attain and assert their identities.

Within the context of cultural identity, the black people were positioned as an 'other' in the colonial experience, consequently, a great number of writers left their homelands and went to settle in other territories. As a result of this dislocation, a feeling of ambivalence is generated, i.e., a confusion between an old historic culture and a new relatively odd location and culture which are often presented in their postcolonial discourse. This throws the light on identity construction which is formed not by identifying with the ancestral place, but through the moving migrant persons and cultures.

Another prominent figure in the 20th century is Edward Saïd. Saïd's writings are very influential in the field of cultural studies and one of the most outstanding studies in that field is Saïd's Orientalism (1977) that deals with the concept of 'We' versus 'Other' or the 'Orient' and the 'Occident'. The idea of the West versus the other reflects the western tendency to assert itself over and against non-western cultures. In addition, Saïd illustrates how Europe has conceived its identity as a superior one in comparison with all the non- European peoples and cultures. Edward Saïd refers to the notion of emphasizing the marginalized group in an attempt to draw attention to the position of those in power. According to Saïd: 'The West is the actor, the Orient is a passive reactor. The West is the spectator, the judge and jury, of every facet of oriental behaviour.' (110)

When discussing the African quest for a distinctive cultural identity as a means of resistance, one can find that they adopt a hybrid identity. Hybridity is considered a characteristic feature of the postcolonial period that is considered a means of forming models of cultural exchange. According to Bill Aschcroft in The Empire Writes Back (1989):

The transaction of the postcolonial world is not a one-way process in which oppression obliterates the oppressed or the colonizer silences the colonized in absolute terms. In practice it rather stresses the mutuality of the process. It lays emphasis on the survival even under the most potent oppression of the distinctive aspects of the culture of the oppressed, and shows how these become an integral part of the new formations which arise from the clash cultures characteristic of imperialism. (183).

Thus, just as the brutality of apartheid provokes resistance on the political and social levels, it also incites defiance in literature. The African suffering is intolerable and the Africans realize that their identity should be obvious in every aspect in their lives. Actually, literature in general and the novel in particular become a means of probing and elucidating contemporary life in Africa and enhancing social awareness. 
So, moving from post-colonialism in general to Postcolonial literature in particular, the latter could be viewed as a term that encompasses a wide range of contemporary writings. In Colonial and Postcolonial Literature: Migrant Metaphors (1995), Elleke Boehmer states: 'It is writing that sets out in one way or another to resist colonial perspectives' (3). Thus, postcolonial literature is not created in the colonies, it is a sort of literature created after independence and by people who are displaced by colonialism and living in metropolitan cultures.

Usually writers writing postcolonial literature have a problem with cultural identification. They survive, although differently, with the notion of home and belonging even when they are far away from their homelands.

As this study focuses on the post-colonial and postmodern aspects in Obama's discourse, it is worth noting here to refer to postmodernism. In his book The Postmodern Turn: Essays in Postmodern Theory and Culture (1997) Ihab Hassan Claims:

The postmodern focus on otherness, difference and heterogeneity is also in part a function of decolonization and of the immigration of people of color all over the earth. Vast migrations and Diasporas of people of color mostly to the metropolitan cores of the more developed countries have created new fusion of cultures and hybrid identities. Globalization thus involves the circulation of difference and otherness as well as homogenization (14)

It is important to understand that Obama's writing is based on the idea of decolonization and destruction. Postmodernism is based on the idea of destructing any source of authority whereas; post colonialism is concerned with the idea of destructing the colonial authority. The study at hand clearly reflects the idea of destruction that both postmodernism and post colonialism aim at through representing the concept of 'self' and 'other' as well as 'us' and 'them'.

Actually, the study focuses on a postcolonial and postmodern discourse produced after the Second World War. The Second World War has both positive as well as negative consequences. Although, the Second World War led to both destruction and death, one of its positive consequences is that of globalization. Globalization as well has some positive and negative consequences. Although it positively affected all fields of life namely, culture, politics and literature, it leads to global fragmentation due to the domination of the wealthy over the poor which capitalism and imperialism planted that in turn lead to the clash of civilizations. What could prove this idea is the terrorist act that takes place in the two towers in 9/11 in the United States of America. This terrorist act shows that in spite of the fact that globalization unifies people, it also differentiates them and although it creates friends, it creates enemies as well.

However, before moving to the analysis of Obama's autobiography Dreams from My Father, it is important first to differentiate between fiction, nonfiction and autobiography. To start with, fiction is any narrative text that presents events that are not factual, whereas; nonfiction is the same but deals with factual events like history books for example. An autobiography is an account of a real person's life and it is usually characterized by its method of narration. The narrator or the narrative voice of the discourse may be 'homodiegetic', 'heterodiegetic' or 'autodiegetic' according to the degree of his/her presence in the text. In a book entitled Literary Theory (1996), Terry Eagleton states:

According to Gerard Genette, a narrator may be 'heterodiegetic' (absent from his own narrative), 'homodiegetic' (inside the narrative as in the first person's stories), or 'autodiegetic' (where he is not only inside the narrative but figures as its principal character) (92)

So, what characterizes the autobiographies is the method of narration as the author may address the narratee from a friendly position using the pronouns I/we or may be disguised under the pronoun he/she.

The study seeks an analysis of the literary work of Obama from a cultural perspective highlighting how culture affects the theme and technique used. The theme of hope is reflected in Obama's work through the method of narration. Obama is all the time using the first person narration as he is proud of being black and accepting the difference.

\section{Analysis}

Barack Obama is the son of a white American mother and a black African father who left the family and went to Kenya when Obama was still young. Obama lived with his mother in America until he heard that his father died at that time, he went to Kenya for a visit. Although Obama lived and was bred in America, he has been all the time proud of being black, and has been all the time outspoken about racial issues. In the article Barack Obama and the Politics of Blackness (2007), Walter writes:

Obama begins the cultural presentation with strong asserts: he is of African descent, he married a black woman, he belongs to a black church, and he lives in a racially integrated community. This cultural context alone defines him as very different from the normative black conservative and created the expected access and level of association with the black community that is the starting point for accountability for any black politician. (22)

Dreams from My Father is an autobiography in which Obama tries to find a meaning to his life as a black American. Obama successfully portrayed the idea of identity and his life as a black man in the United States. Moreover, this autobiography clearly reflects the idea of cross culture that his race places him in. Moreover, it discusses issues like race 
and identity; it also presents Obama's views regarding racial discrimination and his hope to unite the divided colors. Obama's concerns were raised from his father who in one of his letters which the novel presents he addressed him to "know where you belong" (114). Thus, Obama asserts:

Whatever my father might say, I knew it was too late to ever truly claim Africa as my home. And if I had come to understand myself as a black American, and was understood as such, that understanding remained unanchored to place. What I needed was a community, I realized, a community that cut deeper than the common despair that black friends and I shared when reading the latest crime statistics, or the high fives I might exchange on a basketball court. A place where I could put down stakes and test my commitments. (115)

Thus, Obama's Dreams from My Father could be described as a journey across continents to trace his double race and understand the circumstances that shaped his character. This journey ends up with Obama accepting his identity as an African-American citizen.

When discussing the theme of racial discrimination, it is noteworthy to say that although Obama was genetically half white, half black, in his youth he was seen as only black in the eyes of the whites. Obama relates an incident in Dreams from My Father:

There was other child in my class, though, who reminded me of a different sort of pain. Her name was Coretta and before my arrival she had been the only black person in our grade. She was plump and dark and didn't seem to have many friends. From the first day, we avoided each other but watched from a distance, as if direct contact would only remind us more keenly of our isolation. (60-61)

In the light of the postmodernist school of writing, narrative technique is very enlightening as it helps to reflect the self inside and outside the text. It gives cohesion to the text since it prevents the text from fragmentation. In Obama's Dreams from My Father Obama is all the time using the homodiegetic method of narration as he is using the pronoun 'I' throughout the whole novel. This homodiegetic speech shows the closeness of Obama to the text and to his place in society. He presents the idea of colliding cultures together in an attempt to find a solution to issues of race and identity. Thus, this memoir is considered to be a journey of an African-American person in an attempt to search for his identity. Obama succeeds in conveying this image through the exciting writing style, narrative technique and the mixture of white and black characters.

\section{Conclusion}

To sum up, the analysis of Obama's writing reveal a number of findings. Obama is all the time proud of being black and is all the time accepting the difference and hoping to unite different colors. He is using the first person narrative technique to assert his acceptance of being black, unlike other writings of similar cultural background where the third person narrative technique is used to assert the sense of alienation. Obama has succeeded to utilize the theme of politics, racial discrimination which resulted from living different cultural backgrounds.

The analysis uncovers how culture, place, time and origin affect Obama's choice of themes and technique. Moreover, Obama is proud of his identity although he belongs to the minority and has a constant dream of uniting the racial groups. Actually, in Obama's autobiographical narrative texts, he is seen to be very proud of being black due to his education, freedom and upbringing.

\section{References}

\section{Primary Source}

Obama B. (1995). Dreams from My Father. New York: Three Rivers Press.

\section{Secondary Sources}

Alexander, F. (1989). Contemporary Modern Novelists. London: Routledge.

Ashcraft, B. and Paul A. (2001). Edward Said. New York: Routledge.

Ashcroft, B., Gareth G. and Helen T. (1989). The Empire Writes Back._London: Routledge.

Asim, J. (2009). What Obama Means: For Our Culture, Our Politics, Our Future. London: Routledge.

Bal, M. (1997). Narratology: Introduction to the Theory of Narrative. University of Toronto Press.

Bennis, P. (2003). Before and After: U.S. Foreign Policy and the War on Terrorism. New York: Olive Branch.

Bertens, H. (1995). The Idea of the Postmodern: A History. London: Routledge.

Best, S. and Douglas K. (1991). Postmodern Theory: Critical Interrogations. NY: Macmillan.

Bhabha, H. (ed). (1990). Nation and Narration. London: Routledge.

Boehmer, E. (1995). Colonial and Postcolonial Literature: Migrant Metaphors. New York: Oxford University Press. 
Brill, S. (2003). After: How America Confronted the September 12 Era. New York: Simon and Schuster.

Carr, A. and Van L., Mary S. (1996). Religion, Feminism and the Family. London: Westminster John Knox Press.

Connor, S. (ed.). (2004). The Cambridge Companion to Postmodernism. Cambridge: Cambridge.

Currie, G. (1990).The Nature of Fiction. Canada: Cambridge.

Dovey, T. (1988). The Novels of J.M. Coetzee : Lacanian Allegories. Cape Town : Donker.

Eagleton, T. (1996). Literary Theory. UK: Blackwell.

Edwards, J. (2008). Postcoloial Literature. New York: Macmillan.

Fanon, F. (1952). Black Skin, White Masks. New York: Grove Press.

---(1968). The Wretched of the Earth. New York: Grove Press.

Fredrick, R. (1972) . A Guide to Contemporary English Novels. New York: The Noonday Press.

Gallagher, S. (1991). A Story of South Africa: J.M. Coetzee's Fiction in Context. Cambridge, Mass.: Harvard Univ. Press.

Goodwin, J. (1994). Price of Honor. London: Warner Books.

Griffiths, G., Bill A., and Hellen T. (2000). Post-colonial Studies: The KeyConcepts. London: Routledge.

Hassan, I. (1997). The Postmodern Turn: Essays in Postmodern Theory and Culture. New York.

Henry, J. (2000). Writing Workplace Culture: An Archeology of Professional Writing. Carbondale, IL: Southern Illinois University Press.

Hunter, J. (1990). Before Novels: The Cultural Contexts of Eighteenth-Century English Fiction. New York: W.W. Norton.

Hutcheon, L. (1988). A Poetics of Postmodernism: Hitory, Theory, Fiction._London: RoutledgE.

Huntington, S. (2003). The Clash of Civivlizations: Remarking of World Order. New York.

Jacobs, R. (2001). A Beginner's Guide to Critical Reading: An Anthology of Literary Texts. London: Routledge.

Kvam, K. and Linda S. (1999). Eve and Adam : Jewish, Christian, and Muslim readings on Genesis and Gender Bloomington: Indiana University Press, 1999.

Lodge, D. (ed.) and Nigel W. (ed.). (2008). Modern Criticism and Theory: A Reader. Harlow: Pearson.

Loomba, A. (1998). Colonialism/post-colonialism. New York: Routledge.

Malpas, S. (2007). The Postmodern. London: Routledge.

Mohan, B. (1993). Eclipse of Freedom: The World of Oppression. West port, CT: Praeger Publisher.

Remnick, D. (2010). The Bridge: The Life and Rise of Barack Obama. London: Longman.

Said, E. (1978). Orientalism. New York: Random, 1978.

Spivak, G. (1987). In Other Words: Essays in Cultural Politics. London: Routledge.

Steele, S. (2008). A Bound Man: Why We Are Excited about Obama and Why He Can't Win. New York: Random.

Susan O. (ed.), and Jose A. (ed). (1996). Narratology: An Introduction. London: Longman.

Walters, R. (2007).'Barack Obama and the Politics of Blackness'. Journal of Black Studies, 38, 7-29

Weaver, M. (1994). “A Fugitive from Injustice.” The New Yorker. 12 September. 35-59. 